\title{
Impact of Stunting on Development of Children Aged 12-60 Months
}

\author{
$1^{\text {st }}$ Setianingsih \\ Department of Pediatric Nursing. \\ (Stikes Muhammadiyah Klaten) \\ Klaten, Indonesia \\ setianingsih@stikesmukla.ac.id \\ $4^{\text {th }}$ Desi Ratnadilah \\ Student of nursing program \\ (Stikes Muhammadiyah Klaten) \\ Klaten, Indonesia \\ desir2737@gmail.com
}

\author{
$2^{\text {nd }}$ Devi Permatasari \\ Department of Maternity Nursing \\ (Stikes Muhammadiyah Klaten) \\ Klaten, Indonesia \\ devipermatasari@stikesmukla.ac.id
}

\author{
$3^{\text {rd }}$ Endang Sawitri \\ Department of family and community \\ Nursing \\ (Stikes Muhammadiyah Klaten)) \\ Klaten, Indonesia \\ endangsawitri@stikesmukla.ac.id
}

\begin{abstract}
Growth failure (Stunting) in children under five years old can cause various developmental disorders, including personal social development, fine motoric, language, gross motoric. Some studies show different results, where nutritional status (stunting) is not related to child development. Objective: This study aims to determine the impact of stunting on the development of children aged 12-60 months in the Ceper Health Center Working Area. Methods: The study used a non-experimental quantitative design with a cross-sectional approach, located in the village of Ngawonggo Ceper with a total sample of 82 toddlers (36 stunting toddlers and 46 non-stunting) aged 12-60 months who were selected using purposive sampling. Nutritional status was measured by comparing height with age (TB/U), and child development data were measured using the Denver Development Screening Test (DDST). Results: The results of the bivariate analysis showed that the development of social personal of $p$ value $(0.083>0.05)$, fine motoric $p$ value $(0.082>0.05)$, language $p$ value $(0.000<0.05)$, gross motoric $p$ value $(0.001<0.05)$, the impact of stunting related to child development is gross language and motor development. Conclusion: there was no relationship to the effect of stunting on social personal development, there was no relationship to the effect of stunting on fine motor, there was a relationship to the effect of stunting on language, and there was a relationship to the impact of stunting on fine motor skills.
\end{abstract}

Keywords - Child development, personal social, fine motoric, gross motoric, social personal, Stunting

\section{INTRODUCTION}

Early detection is a comprehensive screening effort carried out to find deviations in growth and development and to know and recognize risk factors in infants, also called early childhood. Through early detection, it can be seen that the developmental deviation of children early development, deviation of child development from the physical aspects of toddlers including stunting, wasting and overweight [1]

The 0-24 month period is the period that determines the quality of life so it is called the "Golden Period".
Adverse effects that can be caused by nutritional problems at the first thousand days of life $(1,000 \mathrm{HPK})$, one of which is stunting. The impact of stunting in the short term is the disruption of brain development, intelligence, physical growth, and impaired metabolism. Whereas in the long run are cognitive abilities and decreased learning achievement, decreased immunity resulting in easy illness, high risk for the emergence of non-communicable diseases, and uncompetitive quality of work which results in low economic productivity [2].

Stunting is one of the problems that can inhibit growth and development in children. A child is said to be stunted if he or she has height according to age (height / age) less than minus two standard deviations $(<-2)$ or that the toddler's height is shorter than it should be achieved at a certain age[3]. Early detection of short stature in children needs to be done in order to be given as much intervention as possible. Because short stature has an impact on psychosocial aspects, quality of life of children, costs incurred for treatment, environmental facilities. This impact does not only occur in patients, but also in families [4].

Stunting shows the problem of nutrient deficiencies and infections experienced since or even before the birth of a child. Nutrient deficiency before the birth mass and the mass of the first year of life can affect brain development. Child brain development occurs rapidly in prenatal masses and continues in birth masses to early childhood masses. Research shows that a new-born baby has approximately one hundred billion brain cells. The process of maturation and the formation of neurological system connections occurs progressively after the birth process to the early childhood mass. Nutritional deficiencies in the prenatal period to early childhood mass can cause neurological abnormalities and brain development disorders that affect motor skills, cognitive, language, socio-emotional and mental retardation [5].

Stunting can also cause stunted development of the motor system, both in normal children and with certain diseases. Decreased motor function of stunting children 
without congenital errors is related to the low mechanical ability of the triceps muscle due to the slow maturation of muscle function. Research conducted in the Narahenpita area, Colombo in children aged 36-54 months showed gross motor skills, and fine motor skills in stunting children was lower than in normal children [6].

Stunting conditions can also affect a child's social personal abilities. Children with a stunting condition will usually look apathetic and tend to be reluctant to play with other people around them so that it will have an impact on the child's personal social development [7].

The prevalence of stunted in Indonesia tends to be static from year to year which can be seen through Nutrition Status Monitoring [8]. The stunting prevalence limit for an area is $20 \%$ so that an area is said to have an acute nutritional problem if the prevalence of short toddlers is above $20 \%$. The results of Basic Health Research in 2013 and 2018 from all provinces in Indonesia, nationally the prevalence of stunting decreased from $37.2 \%$ to $30.8 \%$, although it has declined, but it is still far from the WHO limit. Based on the results of the 2018 Riskesdas, the prevalence of stunting in Central Java also decreased seen in 2013 by $35 \%$ and in 2018 by $31 \%$. The Ministry of Health of the Republic of Indonesia (2017) explained that the results of monitoring nutritional status showed that $27.6 \%$ of children under five were stunted. The government includes stunting issues in priority handling of health problems other than $\mathrm{TB}$ and immunization coverage [9].

\section{METHOD}

Research uses non-experimental quantitative design with cross-sectional approach. The population in this study were toddlers aged 12-60 months in Ngawonggo Village with a total of 82 toddlers. The sample selection technique uses purposive sampling. This research instrument uses the Denver Development Screening Test (DDST) form sheet. The analysis test used is Chi Square.

A survey conducted by researchers in Klaten District obtained results in 34 Districts with a total of 64,044 children under five. Of the 34 Subdistricts, the Ceper Subdistrict is one of the regions in Klaten Regency which has the highest prevalence of stunting number three. Data obtained 71 toddlers have a very short height while 193 toddlers have a short height. Then the researchers screened the development of children using the Denver Development Screening Test there were 10 toddlers as a sample in Ngawonggo Village. Researchers found developmental delays in toddlers who experienced the most stunting were language delay by $30 \%$, gross motor by $20 \%$, fine motor by $15 \%$, social personal $10 \%$ and those who did not experience developmental or normal problems by $25 \%$. So that researchers are interested in examining the impact of stunting on child development.

\section{RESULTS AND DISCUSSION}

\section{A. Univariat Table}

TABLE 1. UNIVARIATE ANALYSIS OF THE RELATIONSHIP OF STUNTING TO THE DEVELOPMENT OF CHILDREN AGED 12-60 MONTHS $(\mathrm{N}=82)$

\begin{tabular}{|c|c|c|}
\hline Variable & Frekuensi & $\%$ \\
\hline $\begin{array}{l}\text { Age: } \\
\begin{aligned} & \\
& \text { Toodler } \\
& \text { Preschool }\end{aligned}\end{array}$ & $\begin{array}{l}31 \\
51\end{array}$ & $\begin{array}{l}37,8 \\
62,2\end{array}$ \\
\hline $\begin{array}{c}\text { gender: } \\
\text { Male } \\
\text { Female }\end{array}$ & $\begin{array}{l}44 \\
38\end{array}$ & $\begin{array}{l}53,7 \\
46,3\end{array}$ \\
\hline $\begin{array}{l}\text { Exclusive breastfeeding: } \\
\text { Yes } \\
\text { No }\end{array}$ & $\begin{array}{l}60 \\
22\end{array}$ & $\begin{array}{l}73,2 \\
26,8\end{array}$ \\
\hline $\begin{array}{l}\text { Low Birth weight: } \\
\text { Yes }(<2500 \mathrm{gr}) \\
\text { No }(>2500 \mathrm{gr})\end{array}$ & $\begin{array}{l}14 \\
68\end{array}$ & $\begin{array}{l}17,1 \\
82,9\end{array}$ \\
\hline $\begin{array}{l}\text { Parent education } \\
\text { high (SMA/D3/S1/S2/S3) } \\
\text { low (SD/SMP) }\end{array}$ & $\begin{array}{l}74 \\
8\end{array}$ & $\begin{array}{l}90,2 \\
9,8\end{array}$ \\
\hline $\begin{array}{l}\text { Parent income: } \\
\text { High }(>1.500 .000) \\
\text { low }(<1.500 .000)\end{array}$ & $\begin{array}{l}61 \\
21\end{array}$ & $\begin{array}{l}74,4 \\
25,6\end{array}$ \\
\hline $\begin{array}{l}\text { Nutritional status: } \\
\text { Poor } \\
\text { Good }\end{array}$ & $\begin{array}{l}28 \\
54\end{array}$ & $\begin{array}{l}34,1 \\
65,9\end{array}$ \\
\hline $\begin{array}{l}\text { Social personal development: } \\
\text { Advanced } \\
\text { Normal } \\
\text { Caution } \\
\text { Delayed }\end{array}$ & $\begin{array}{l}10 \\
50 \\
21 \\
1\end{array}$ & $\begin{array}{l}12,2 \\
61,0 \\
25,6 \\
1,2\end{array}$ \\
\hline $\begin{array}{c}\text { Fine motor development: } \\
\text { Advanced } \\
\text { Normal } \\
\text { Caution } \\
\text { Delayed }\end{array}$ & $\begin{array}{l}8 \\
53 \\
20 \\
1\end{array}$ & $\begin{array}{l}9,8 \\
64,6 \\
24,4 \\
1,2\end{array}$ \\
\hline $\begin{array}{l}\text { Language development: } \\
\text { Advanced } \\
\text { Normal } \\
\text { Caution } \\
\text { Delayed }\end{array}$ & $\begin{array}{l}3 \\
58 \\
20 \\
1\end{array}$ & $\begin{array}{l}3,7 \\
70,7 \\
24,4 \\
1,2\end{array}$ \\
\hline $\begin{array}{l}\text { Gross motor development: } \\
\text { Advanced } \\
\text { Normal } \\
\text { Caution } \\
\text { Delayed }\end{array}$ & $\begin{array}{l}8 \\
44 \\
29 \\
1\end{array}$ & $\begin{array}{l}9,8 \\
53,7 \\
35,5 \\
1,2\end{array}$ \\
\hline $\begin{array}{l}\text { Stunting: } \\
\text { Stunting } \\
\text { Normal }\end{array}$ & $\begin{array}{l}36 \\
46\end{array}$ & $\begin{array}{l}43,9 \\
56,1\end{array}$ \\
\hline Sum & 82 & 100 \\
\hline
\end{tabular}

\section{B. Bivariate}

TABLE 2. CHI SQUARE ANALYSIS OF THE RELATIONSHIP OF STUNTING WITH THE DEVELOPMENT OF CHILDREN AGE 12 60 MONTHS $(\mathrm{N}=82)$

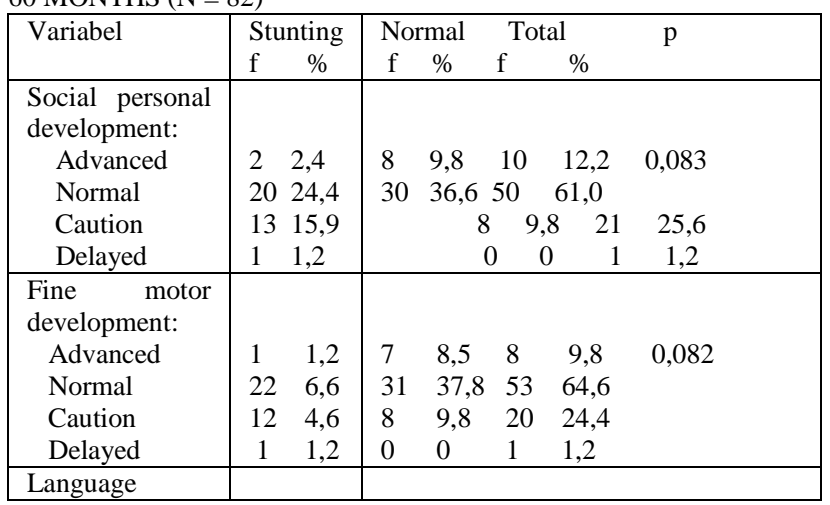




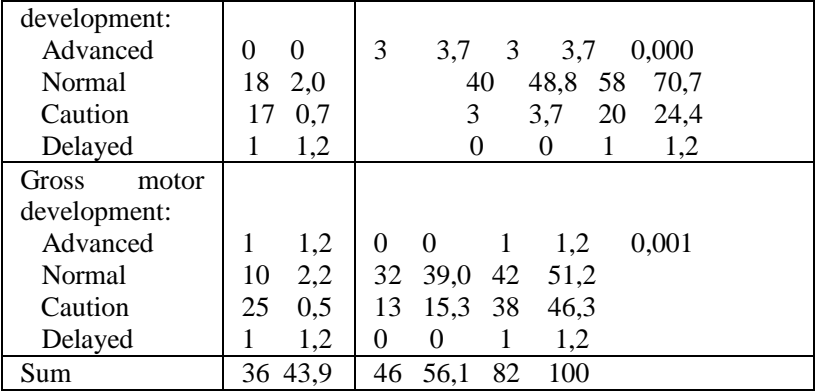

Based on table 2 it can be seen that the relationship of stunting with social personal development with a $\mathrm{p}$ value of 0.083 means $p$ value> 0.05 so that there is no significant relationship of stunting to the child's social personal development.

Stunting with fine motor development shows an insignificant relationship. The p value is 0.082 ( $p>0.05)$.

Language development with stunting shows a $\mathrm{p}$ value of 0,000 ( $p$ value <0.05) so that there is a significant relationship of the impact of stunting on children's language development.

The impact of stunting when associated with gross motor development shows the results of the $\mathrm{p}$ value of 0.001 ( $\mathrm{p}$ value $<0.05$ ). It can be concluded that there is a significant relationship between stunting and children's gross motor development.

\section{Relationship stunting on social personal development}

The results of this study are consistent with research conducted by [10] where the social personal development has no significant relationship with the impact of stunting on children aged 12-60 months.

The personal social development of stunting toddlers does not overall experience delays, this is because the family environment has given attention and support to children, so they can still get along well in their environment regardless of nutritional status. A child who has been able to improve social skills, has indirectly been able to make social adjustments as a form of children's success to adjust to others. Children who get stimulation will be able to develop their abilities within the limits given by the family or environment. This is likely to be the reason why personal social development has nothing to do with the impact of stunting [10].

\section{Relationship Stunting on fine motorDevelopment}

The results of bivariate analysis revealed that a $\mathrm{p}$ value of 0.082 meant $p$ value $>0.005$ so that there was no effect of stunting on children's fine motor development.

These results are the same as the research conducted by Suryaputri et al, with the Chi Square test results ( $p$ > 0.05 ) showing that the nutritional status of stunting and obesity is not related to the child's motor ability. Fine motor skills in children with nutritional status stunting can develop rapidly without a significant increase in body length according to age and influence by optimal stimulation from parents, especially mothers [11].

\section{E. Relationship Stunting on Language Development}

The results of this study indicate a $\mathrm{p}$ value of 0,000 means $\mathrm{p}$ value $<0.005$ so there is a stunting relationship to children's language development.

These results are consistent with research conducted by Hanum \& Khomsan (2017), which shows a significant difference ( $p$ value $<0.05$ ) on achievement of language and cognitive development scores based on toddler age in the normal and stunted toddlers group. Stunted toddlers are only able to achieve simple language development tasks and it is difficult for them to fulfill more complex language development tasks according to their age stages because of their lower cognitive abilities [12].

According to Kar, Rao \& Chandramouli, as age increases, the level of language complexity in children will increase [13]. Research from Hanum also shows supportive results where there are differences in vocabulary that can be achieved by $50.0 \%$ in normal toddlers and only $20 \%$ can be achieved by stunting toddlers [12].

Research Alina Hizni, Madarina Julia, (2010) states that language is closely related to the development of individual thought power, namely the ability to form understanding, form opinions and draw conclusions. The motor aspect of speech is associated with the ability to make certain sounds known as words, while the mental aspect of speech is related to the ability to gather meaning with those words [10].

Stunting shows the manifestations of nutrient deficiency problems and infections experienced since or even before the birth of a child (in the long term). Nutrient deficiencies before the birth mass and in the mass of the first year of life can affect brain development. Child brain development occurs rapidly in prenatal masses and continues after birth masses to early childhood masses. Research shows that a newborn baby has approximately one hundred billion brain cells. The process of maturation and the formation of neurological system connections occurs progressively after the birth process to the early childhood mass. Nutritional deficiencies from prenatal to early childhood mass can cause neurological disorders and brain development disorders that affect cognitive and language abilities so that children with a history of stunting in early childhood have limited vocabulary and a low level of intelligence [5]

\section{F. Relationship Stunting on gross motoric Development}

The results of this study indicate that gross motor development in stunted children is delayed. The results of bivariate analysis of $\mathrm{p}$ value of 0.001 means $\mathrm{p}<0.005$ so that there is a significant relationship between stunting on children's gross motor development.

These results are consistent with research conducted by Suwandi, (2018) which states that in children aged 1-3 years who experience more stunting experience a delay in gross motor development $(87.5 \%)$ whereas in children with normal nutritional status most of them experience gross motor development normal (76.5\%) [14]. The results of other supportive studies are from Pantaleon, Hadi and Gamayanti, namely children who are stunted 
have an 11.98 times greater chance of having below average motor development [15].

Nutritional status greatly affects the growth and development of children. Children whose nutritional status is lacking will have an impact on the lack of optimal muscle tissue in children which will certainly affect the child's movements. This study is in line with research Solihin, (2013) that nutritional factors are influential in optimizing gross motor development in children [6]. This is likely related to motor development controlled by a part of the brain when experiencing nutritional problems, namely chronic stunting that can result in changes and functions of brain development, namely reducing the number of nerve cells, reducing the function, structure and role of neurotransmitters in the brain. Part of the brain precisely the cerebellum is the center of motor movement which will have an impact if affected by nutritional problems. In addition, the first three years of age is an age that is susceptible to experiencing nutritional problems that can affect the development of a child's brain [16].

Children who experience late gross motor development can still be improved because in these times children are still quick to follow or imitate the direction of those around them, especially parents. Stunting can still be improved by providing a balanced nutritional intake because height growth can still be pursued until children are $>18$ years old [14].

In accordance with the research of Setianingsih, R. Nov. and J. Juniarsih (2018) that socioeconomic factors are one of the factors that influence children's development. There is a negative relationship between socioeconomic status with the ability to focus attention and hyperactivity of children. High socioeconomic status is believed to influence the maintenance of children's health, nutritional fulfillment, stimulation of child growth and development and high knowledge of parents in caring for children [17]

\section{CONCLUSION}

The results of this study indicate the relationship of stunting to child development is as follows, stunting is not related to social personal development with a $p$ value of 0.083 ( $p>0.05)$. Stunting is not related to fine motor development with a $p$ value of $0.082(p>0.05)$. Stunting is related to language development with a $\mathrm{p}$ value of 0,000 $(p<0.05)$. The impact of stunting is related to gross motor development with a $\mathrm{p}$ value of $0.001(\mathrm{p}<0.05)$.
The results of this study recommend that parents increase their nutritional needs in the golden period. Increase screening for children's growth and development in an effort to detect delays early. For future researchers, it is recommended to develop research methods by comparing the development of stunting and non-stunting children, examining the factors that most influence the occurrence of stunting.

\section{REFERENCES}

[1] A. N. Chamidah, "Deteksi Dini Gangguan Pertumbuhan dan Perkembangan Anak," Pendidik. Khusus, vol. 1(3), 2012.

[2] Kemenkes, "InfoDatin:Situasi Balita Pendek," 2016.

[3] Soetjiningsih, Perkembangan Anak Edisi 2. Jakarta: egc, 2015.

[4] Soetjiningsih, Perkembangan Anak Edisi 2. Jakarta: EGC, 2015.

[5] K. G. Prado, E. L., \& Dewey, "Nutrition and brain development in early life.," vol. 72(4), pp. 267-284, 2014.

[6] dan D. S. Solihin RDM , Faisal Anwar, "Kaitan Antara Status Gizi, Perkembangan Kognitif, dan Perkembangan Motorik Pada Anak Usia Prasekolah," Penelit. Gizi Dan Makanan, vol. 36(1), pp. 62-72., 2013.

[7] F. A. A. Hassan, "Preschool Child Development in Egypt. Suez Canal University," Suez Canal Univ. Med. Journal., vol. 16(1), pp. 1-10, 2014.

[8] Kementrian Kesehatan RI, "Situasi Balita Pendek (stunting) di Indonesia," Kementeri. Kesehat. RI, vol. 1, pp. 1-43, 2018.

[9] Setyawati, "Situasi stunting di jawa tengah," 2018

[10] I. L. G. Alina Hizni, Madarina Julia, "Status stunted dan hubungannya dengan perkembangan anak balita di wilayah pesisir Pantai Utara Kecamatan Lemahwungkuk Kota Cirebon," GIZI Klin. Indones., vol. 6(3), pp. 131-137, 2010.

[11] R. B. C. dan A. D. Suryaputri Indri Yunita, "DETERMINAN KEMAMPUAN MOTORIK ANAK BERUSIA 2-5 TAHUN: STUDI KASUS DI KELURAHAN KEBON KALAPA BOGOR.," vol. 37(1), pp. 43-50, 2014.

[12] A. Hanum, N. L., \& Khomsan, "Pola Asuh Makan, Perkembangan Bahasa, Dan Kognitif Anak Balita Stunted Dan Normal Di Kelurahan Sumur Batu, Bantar Gebang Bekasi," J. Gizi Dan Pangan, vol. 7(2), 2017

[13] B. A. Kar, B. R., Rao, S. L., \& Chandramouli, "Cognitive development in children with chronic protein energy malnutrition," Behav. Brain Funct., vol. 4, pp. 1-12, 2008.

[14] A. R. Suwandi, "HUBUNGAN STATUS GIZI ( TB / U ) TERHADAP PERKEMBANGAN MOTORIK KASAR PADA ANAK USIA 1-3 TAHUN DI WILAYAH KERJA PUSKESMAS KORPRI.," vol. 01(01), pp. 3-6, 2018.

[15] I. L. Pantaleon, M. G., Hadi, H., \& Gamayanti, "Stunting berhubungan dengan perkembangan motorik anak di Kecamatan Sedayu, Bantul, Yogyakarta,” 2015.

[16] D. R. S. Hesty Dwi Septiawahyuni, "Adequacy of Zinc Intake is Related to Motoric Development among Stunted and Non-Stunted Toddler.," pp. 1-6, 2019.

[17] J. Setianingsih, S., Novi, R., \& Juniarsih, "Low Socio Economic Status Risk Improving Attention Deficit and Hiperactivity Disorder in Preschoolers," J. Ilmu Keperawatan Anak, vol. 1(2), p. 30, 2018. 